\title{
MEMBACA REALITAS BULLYING DI SEKOLAH : TINJAUAN MULTIPERSPEKTIF SOSIOLOGI
}

\author{
Ariefa Efianingrum \\ Jurusan Teknologi Kebijakan Pendidikan, FIP, UNY \\ Email : efianingrum@uny.ac.id
}

\begin{abstract}
Abstrak
Bullying merupakan jenis kekerasan spesifik yang seringkali hadir tanpa disadari dalam suatu relasi sosial. Bullying dapat terjadi dalam berbagai konteks, termasuk di dalam sistem persekolahan. Intensitas bullying di sekolah menunjukkan peningkatan dengan jenis yang semakin beragam, seperti verbal bullying, physical bullying, sexual bullying, emosional bullying, dan cyber bullying. Dalam perspektif sosiologi, tidak ada jawaban tunggal dalam menjelaskan realitas sosial karena sosiologi merupakan ilmu sosial berparadigma ganda. Demikian juga dalam menjelaskan realitas bullying di sekolah. Tulisan ini mencoba mengurai tentang bullying di sekolah dalam multiparadigmatik sosiologi, yaitu paradigma determinisme struktur (makro objektif), determinisme agen (mikro subjektif), dan pemaduan (kontinum) di antara keduanya. Tinjauan tentang bullying di sekolah ini penting dilakukan supaya penjelasannya tidak parsial sehingga dapat memberikan pemahaman yang lebih komprehensif. Pilihan teoretik tersebut memiliki implikasi metodologis yang selanjutnya diharapkan bermuara pada ditemukannya solusi yang tepat. Langkah solutif untuk prevensi dan mengatasi bullying perlu dilakukan untuk mengembangkan relasi sosial menjadi lebih harmonis dan humanis.
\end{abstract}

Kata kunci: bullying di sekolah, perspektif sosiologis

\section{Abstract}

Bullying is a specific violence in an imbalance power of social relation. Bullying occurs in various contexts, including in the schooling systems, namely school bullying. The intensity of school bullying increases in various forms, such as verbal bullying, physical bullying, sexual bullying, emotional bullying, and cyber bullying. Sociology is a social science with multiple paradigms. This paper explains about school bullying from multiple paradigms of sociology such as structural determinism (macroobjective), agency (micro-subjective), and continum between agency and structure. It is important to analyze school bullying comprehensively. Theoretical references have methodological implications that lead to finding solutions to overcome school bullying from sociological persepectives.

Keywords: school bullying, sociology, multiple paradigm

\section{Pendahuluan}

Pendidikan merupakan proses mengembangkan aspek pengetahuan, perasaan, dan keterampilan secara utuh bagi bertumbuhnya jiwa, rasa, dan raga manusia secara menyeluruh. Sekolah sebagai salah satu institusi pendidikan juga dipercaya oleh masyarakat sebagai proses pembudayaan sekaligus sebagai wahana pengembangan potensi kemanusiaan. Namun sayangnya dalam sejumlah 
kasus, justru menunjukkan bahwa sekolah dapat menjadi tempat berlangsungnya kekerasan dan bullying yang tidak sesuai dengan nilai-nilai karakter dan kemanusiaan itu sendiri. Dalam perkembangannya, bullying yang melibatkan warga sekolah bahkan hadir dalam berbagai bentuk, dengan pelaku individual maupun kolektif, dan mengakibatkan dampak yang beragam bagi para korbannya.

Angka bullying di sekolah menunjukkan prevalensi yang semakin meningkat di sejumlah tempat. Ekspose data hasil pengawasan Komisi Perlindungan Anak Indonesia (KPAI) khususnya di bidang pendidikan menunjukkan bahwa selama 2018 paling banyak terjadi kasus anak pelaku kekerasan dan bullying. Adapun kategori kasus yang diawasi antara lain adalah: anak yang menjadi korban tawuran, anak yang menjadi pelaku tawuran, anak yang menjadi korban kekerasan dan bullying, anak yang menjadi pelaku kekerasan dan bullying, serta anak yang menjadi korban kebijakan (misalnya: pungutan liar, dikeluarkan dari sekolah, tidak boleh mengikuti ujian, dan putus sekolah). Menurut data KPAI, jumlah kasus pendidikan per tanggal 30 Mei 2018, dari 161 kasus, terdapat anak korban tawuran sebanyak 23 kasus atau 14,3 persen, anak pelaku tawuran sebanyak 31 kasus atau 19,3 persen, anak korban kekerasan dan bullying sebanyak 36 kasus atau 22,4 persen, anak pelaku kekerasan dan bullying sebanyak 41 kasus atau 25,5 persen, dan anak korban kebijakan (pungli, dikeluarkan dari sekolah, tidak boleh ikut ujian, dan putus sekolah) sebanyak 30 kasus atau 18,7 persen. Berdasarkan data tersebut, kasus anak pelaku kekerasan dan bullying menempati peringkat teratas (https://nasional.tempo.co).

Data di atas cukup memprihatinkan, mengingat pendidikan di sekolah diharapkan sebagai wahana penyemaian benihbenih kemanusiaan, namun di sisi lain di sekolah juga dapat terjadi praktikpraktik pelanggaran terhadap nilai kemanusiaan. Pendidikan tidak hadir dalam ruang kosong, melainkan berlangsung dan tumbuh dalam ekosistem dan konteks sosio kultural yang senantiasa mengalami dinamika perubahan. Bullying yang terjadi di sekolah dapat menjadi cerminan dari kekerasan yang terjadi dalam konteks masyarakat luas. Tulisan ini hendak mengkaji realitas bullying dalam persepektif sosiologi. Sebagai ilmu sosial yang berparadigma jamak 
(multiple paradigm), dalam penjelasan

Ritzer (Alimandan, 1992) sosiologi memiliki perspektif yang beragam, seperti: paradigma fakta sosial, paradigma definisi sosial, dan paradigma perilaku sosial. Oleh karenanya suatu realitas sosial tidak hanya dijelaskan dengan menggunakan satu teori, melainkan dengan berbagai ancangan teoretik yang bervariasi pula. Variabilitas teoretik yang berimplikasi pada keragaman pilihan metodologi penelitian, bukannya untuk dipertentangkan, namun dapat digunakan sebagai alternatif sesuai dengan tujuan penelitian. Babbie (2007) memberikan penjelasan tentang perbedaan fokus kajian sebagai berikut:

There are difference concerning focus that stretches across many paradigms. Some social theorists focus their attention on society at large with macro theories topics of study, and some scholars have taken microtheory, a more intimate view of social life deals at individuals level and small groups.

Analisis sosiologi menghadapi tantangan untuk dapat menjelaskan realitas sosial yang kompleks karena realitas empiris maupun acuan teoretisnya merentang di antara perspektif determinisme struktur (makro objektif) dan determinisme agen (mikro subjektif). Dalam perkembangannya, penjelasan tentang bullying di sekolah dapat menggunakan multi pendekatan dan multi metode, baik penelitian kuantitatif maupun kualitatif, bahkan pemaduan keduanya. Telaah yang komprehensif dan mendalam tersebut semakin dirasakan penting dalam menjelaskan bullying sehingga bermuara pada ditemukannya solusi yang tepat untuk mengurangi dan mencegah terulangnya kembali praktik bullying di sekolah pada masa-masa yang akan datang.

\section{Metode}

Pemikiran secara kritis yang tertuang dalam artikel ini dilakukan dengan penggunaan kajian pustaka sebagai literatur sehingga dapat mengkaji permasalahan sosial yakni mengenai tindak bullying sebagai salah satu jenis tindak kekerasaan. Studi literatur dengan menggunakan berbagai sumber yang memuat pustaka sesuai dengan bidang kajian seperti buku, artikel jurnal hasil penelitian maupun berita secara online yang relevan untuk dipelajari sehingga menguatkan pemikiran kritis mengenai tindakan bullying di sekolah. Melihat fokus permasalahan kemudian dilakukan 
dengan analisa berdasarkan sumber pustaka sehingga melahirkan pemikiran kritis yang diharapkan dapat memperkaya pengetahuan mengenai tindak kekerasan tersebut.

\section{Hasil dan Pembahasan}

\section{Kekerasan dan Bullying di Sekolah}

Bullying merupakan salah satu jenis kekerasan yang sifatnya spesifik. Kekerasan merupakan segala bentuk tindakan yang mengganggu pihak lain dan memiliki implikasi personal yang beragam. Bagi Galtung (Erich Fromm, 2008), kekerasan terjadi apabila kecenderungan untuk tumbuh dan berkembang dihalangi, karena energi yang terhalang itu dapat beralih menjadi energi yang destruktif melalui tindakan agresif. Kekerasan merupakan setiap tindakan yang mengganggu orang lain, baik fisik maupun psikologis (Salmi, 2005). Kekerasan mengandung tindakan yang dilakukan dengan pemaksaan, kemarahan, kejengkelan, maupun frustasi yang kesemuanya merupakan bagian dari emosi negatif yang kuat (Soehardi dalam Sumjati, 2001). Kekerasan merupakan bagian dari konflik dan tragedi kemanusiaan yang memerlukan penjelasan sosio-historis (Affandi, 2004). Sedangkan Salmi
(2003) mengungkapkan bahwa kekerasan bukan semata-mata sebagai akibat dari kecelakaan sejarah, penyimpangan yang tidak terduga, atau kebetulan semata, melainkan sebagai buah langsung dari kapitalisme. Kekerasan merupakan tindakan yang bertentangan dengan nilai kehidupan dan kemanusiaan.

Berdasarkan pelakunya, Douglas \& Waksler (Santoso, 2002) mengidentifikasi bahwa kekerasan dapat bersifat individual dan kolektif yang dilakukan oleh sekelompok orang dengan berbagai bentuk. Kekerasan mengilustrasikan terjadinya pelanggaran terhadap aturan sosial yang berlaku di masyarakat. Tindakan kekerasan kemudian menjadi penanda adanya penyimpangan sosial yang berimplikasi pada munculnya stigmastigma sosial. Selanjutnya bagi Douglas \& Waksler (Assegaf, 2004), kekerasan digambarkan sebagai perilaku yang disertai dengan penggunaan kekuatan kepada orang lain. Umumnya kekerasan dilakukan oleh pihak yang memiliki kekuatan lebih. Sedangkan Olweus menjelaskan kekerasan sebagai perilaku agresif sehingga menimbulkan ketidaknyamanan hingga cidera yang serius terhadap orang lain. WHO juga memberikan definisi kekerasan sebagai penggunaan daya 
dan kekuatan yang dapat membahayakan fisik maupun kejiwaan (Cowie \& Jenifer, 2009).

Sebagai salah satu kekerasan yang spesifik, bullying didefinisikan sebagai segala bentuk kekerasan dan penindasan yang dilakukan oleh seseorang atau sekelompok orang yang memiliki kekuasaan dengan sengaja bertujuan untuk menyakiti secara terus menerus (Ken Rigby, 2002).

Bullying as the systemic abuse of power can be occurred in various contexts. Rigby presents how bullying occurs in schools (Spears, 2003).

Sementara itu Olweus (Cowie \& Jennifer, 2009) menjelaskan bahwa bullying terjadi ketika siswa mengalami tindakan negatif secara berulang. Sifatnya yang terus menerus dan dilakukan berulang-ulang dengan pelaku yang memiliki kuasa lebih merupakan penciri bullying dibandingkan dengan kasus-kasus kekerasan yang lain. Sejumlah literatur menjelaskan bahwa penyebutan bullying sering disamakan artinya dengan pembulian, perundungan, penindasan, atau penggencetan.

Bullying terjadi dalam berbagai bentuk, seperti verbal bullying (kata-kata, ucapan), phisycal bullying (tindakan fisik), emotional bullying (fisik), sexual bullying (seksual), dan cyber bullying (bullying di dunia maya). Pada masa lalu, bullying lebih sering bersifat fisik dan konfrontatif, namun saat ini bullying seringkali bersifat simbolis dan tersembunyi (Van Stone, 2012). Bullying terjadi dalam berbagai konteks, karena dapat terjadi di dalam keluarga, di sekolah, dalam pergaulan dengan teman sebaya, dan dalam masyarakat. Hal tersebut menepis anggapan bahwa sekolah merupakan tempat yang aman dan bebas dari kekerasan, karena kekerasan seringkali justru terjadi dengan melibatkan aktor-aktor di sekolah (Harlin, 2008).

Bullying menjadi masalah yang meluas dalam sistem sekolah. Bahkan disinyalir, hampir setiap anak pernah mengalami bullying (Annot, 2006). Bullying di sekolah merupakan implikasi adanya interaksi sosial antara pelaku dan korban yang sama-sama menjadi warga sekolah, kultur sekolah dan iklim kelas yang kurang kondusif untuk belajar, serta perilaku warga sekolah yang mengabaikan tindakan bullying. Penelitian disertasi Ariefa (2018) tentang reproduksi kekerasan pelajar di Yogyakarta menjelaskan bahwa fenomena kekerasan termasuk di dalamnya bullying yang dilakukan oleh pelajar di sekolah, pelakunya dapat bersifat individual (perorangan) 
maupun secara kolektif (berkelompok). Dalam kasus kekerasan pelajar, pada umumnya pelaku kolektif adalah pelajar yang tergabung dalam aktivitas geng pelajar. Dake (2003) mengungkapkan bahwa meningkatnya prevalensi bullying di sekolah mensyaratkan pentingnya bullying menjadi isu utama dan prioritas sekolah yang perlu penanganan.

\section{Bullying dari Multiperspektif Sosiologi}

Dalam menguraikan realitas bullying di sekolah, terdapat beragam pilihan dalam menjelaskan secara teoretik dalam ilmu-ilmu sosial, khususnya sosiologi. Keragaman tersebut mendasarkan dan mengikuti paradigma yang berbeda pula. Jika mengacu pada sosiologi dari Ritzer (2012), paradigma dapat dikategorikan menjadi paradigma fakta sosial, definisi sosial, dan perilaku sosial. Ritzer (Alimandan, 1993) memaknai paradigma sebagai cara pandang terhadap sesuatu atau premis teoretis yang berimplikasi secara metodologis dalam menjelaskan realitas sosial, dan sebagai gambaran dasar pokok perhatian dalam suatu ilmu. Adapun penjelasan tentang masing-masing paradigma dijelaskan lebih lanjut oleh Ritzer sebagai berikut: a) paradigma fakta sosial memusatkan perhatian pada fakta-fakta sosial atau struktur dalam institusi sosial berskala besar (makro struktur) beserta pengaruhnya terhadap tindakan individu dan kolektif. Adapun teori yang berada dalam paradigma ini antara lain: teori fungsional struktural, teori konflik, dan teori sistem, b) paradigma definisi sosial mengarahkan minat kajian pada cara aktor sosial memberikan definisi terhadap situasi sosial yang mereka alami dan dampaknya bagi tindakan dalam interaksi. Sejumlah teori yang termasuk dalam paradigma ini adalah: teori interaksionisme simbolik, fenomenologi, dan etnometodologi, c) paradigma perilaku sosial yang memusatkan pokok persoalan pada posisi individu sebagai subjek pasif yang dikontrol dan tunduk pada struktur sosial yang bermuatan nilai dan sistem aturan.

Sedangkan dalam kategorisasi yang berbeda, multiperspektif sosiologi juga dapat dipetakan menjadi: pendekatan determinisme struktur (makro objektif), determinisme agen (mikro subjektif), dan kontinumitas agensi struktur (pemaduan keduanya). Pendekatan diterminisme struktur menganalisis bahwa problematika sosial disebabkan oleh faktor struktur sosial, pendekatan determinisme agen 
mengkaji bahwa problem sosial ditentukan oleh aktor tindakan tersebut, dan pendekatan kontinumitas agensi struktur melihat bahwa problem sosial merentang di antara struktur dan agen. Ketiga perspektif tersebut dapat digunakan dalam menganalisis fenomena bullying.

1. Pendekatan Determinisme Struktur Pendekatan ini memiliki asumsi bahwa individu merupakan objek yang perilakunya dikontrol oleh struktur. Individu patuh terhadap struktur sosial yang melingkupi dan seolah-olah tidak berdaya dalam mengkonstruksi ulang struktur sosial sebagaimana dijelaskan oleh Sugeng Bayu Wahyono (Septiarti, 2017). Dengan kata lain, fakta sosial berada di luar diri individu (external) dan bersifat memaksa (coertion) untuk bertindak. Pendekatan makro struktural ini jika digunakan untuk melihat fenomena bullying di sekolah, akan menjelaskannya sebagai akibat dari faktor struktural yang bersifat eksternal. Adapun metode penelitian yang sesuai dengan pendekatan ini adalah penelitian kuantitatif untuk menjelaskan hubungan dan pengaruh antar variabel (korelasional).

Contoh penelitian yang menggunakan pendekatan determinisme struktur antara lain adalah "Perkelahian Pelajar: Potret
Siswa SMU di Jakarta" oleh Hasballah M. Saad (2003) yang menjelaskan adanya hubungan dan pengaruh kuat antara sejumlah faktor utama seperti kondisi lingkungan tempat tinggal, kualitas hubungan remaja dengan orangtuanya, dan konsep diri remaja terhadap agresivitas remaja. Asumsi makro struktural melihat faktor struktur sebagai penentu atas tindakan agresif remaja dalam berbagai manifestasinya. Pendekatan ini berfokus pada struktur dan mengabaikan faktor agen, karena remaja dilihat sebagai objek pasif yang perilakunya selalu dikontrol oleh struktur sosial.

Selain itu, Sidik Jatmika (2010) dalam risetnya tentang "Geng Remaja: Anak Haram Sejarah ataukah Korban Globalisasi?" juga menyatakan bahwa geng remaja merupakan fenomena sosial buah dari sejarah dan interelasi sosial-politik pada konteks global, nasional, maupun lokal. Keberadaan geng remaja sangat dipengaruhi oleh perubahan sosial dan globalisasi yang mengiringi suasana zaman. Pada level makro, keberadaan geng sekolah merupakan representasi masyarakat dan berkaitan erat dengan situasi politik pada masanya karena memiliki jaringan dengan kelompok pemuda di luar sekolah. 


Pendekatan determinisme
struktural memiliki asumsi bahwa
problem sosial disebabkan oleh faktor
eksternal dalam struktural sosial.
Struktur sosial yang berubah dapat
menyebabkan terjadinya problem
sosial seperti kekerasan dan bullying.
Bullying yang terjadi di sekolah
merupakan refleksi kekerasan di
masyarakat. Nilai-nilai yang kuat dalam
struktur sosial dapat mengontrol
perilaku individu supaya tertib,
harmonis, dan integratif.

2. Pendekatan Determinisme Agen

Pendekatan ini menjelaskan bahwa individu merupakan makhluk kreatif yang memiliki posisi tawar dan mampu bernegosiasi dengan struktur sosial. Manusia sebagai individu maupun kelompok memiliki posisi sebagai penafsir yang mendefinisikan struktur melalui interpretasi, pemaknaan, dan pemahaman tertentu. Penjelasan tersebut senyampang dengan ulasan Tjaya \& Sudarminta (2005) tentang manusia sebagai subjek penafsir. Sebagai subjek aktif, manusia tidak sekedar pasif menerima, namun memiliki peluang dalam melakukan resistensi dan rekonstruksi terhadap struktur sosial. Argumen dari pendekatan determinisme agen ini berbeda dengan pendekatan determinisme struktur. Pendekatan determinisme agen memposisikan pelaku bullying sebagai subjek yang berusaha merespon struktur sosial secara aktif. Metode penelitian yang sering digunakan dalam pendekatan ini adalah penelitian kualitatif untuk menggali realitas bullying secara lebih mendalam.

Contoh studi yang dilakukan oleh Supriyanto Abadi dkk (2009) mengikuti argumen aktor kekerasan sebagai agen. Dalam buku berjudul "Agen-agen Kekerasan: Studi atas Kelompok Sipil di Yogyakarta" dijelaskan bahwa setelah berakhirnya rezim Orde Baru dan memasuki era reformasi, telah terjadi kemunduran negara khususnya dalam bidang keamanan. Dalam kondisi tersebut, jaringan bisnis dan politik keamanan berkembang dengan ditandai oleh menjamurnya para agen dan broker keamanan dengan beraneka pola relasi di antara aktoraktor negara dan aktor-aktor atau organisasi-organisasi non negara. Kelompok-kelompok keamanan dan kekerasan tersebut diduga berafiliasi dengan elite politik lokal dengan beranggotakan para pemuda termasuk di dalamnya para pelajar. Kelompokkelompok tersebut sering memberikan bantuan dan dukungan ketika tawuran pelajar terjadi. Kajian ini melihat geng 
pelajar berafiliasi dengan kelompok pemuda luar sekolah dan kelompok keamanan dalam masyarakat.

Kajian tersebut menunjukkan bahwa analisis fenomena bullying oleh pelajar di sekolah dilihat dari sudut mikro konstruktivis. Sebagaimana studi Habib Kadir (2010) bahwa keterlibatan pelajar dalam geng sekolah yang sering melakukan kekerasan dan bullying merupakan kebutuhan untuk merayakan kesenangan di masa mudanya. Mereka mengembangkan loyalitas antar anggota geng dengan saling memberikan dukungan sosial satu sama lain. Perspektif yang berbeda akan berimplikasi pada pilihan metode yang berbeda pula. Pendekatan determinisme agen lebih tepat menggunakan metode verstehen (pemahaman).

Pendekatan determinisme agen ini mengandaikan bahwa setiap individu memiliki kemampuan untuk memahami, menginterpretasi, dan memaknai dunia sekitarnya sebagaimana tercermin pada tindakan sosialnya. Oleh karenanya, metode penelitian kualitatif lebih sesuai untuk menjadi pilihan dalam perspektif ini.

3. Kontinumitas Agensi-Struktur

Pendekatan ini direpresentasikan oleh beberapa teori, seperti teori strukturasi dari Anthony Giddens dan teori strukturalisme genetik dari Pierre Bourdieu. Tulisan ini lebih fokus menggunakan platform pemikiran Bourdieu dalam upaya mengatasi pilihan antara determinisme struktur (makro objektif) dengan determinisme agen (mikro subjektif). Bourdieu berupaya menghindari penjelasan yang deterministik terhadap problem sosial (Jenkins, 2010). Bourdieu menggunakan konsep habitus untuk menjembatani dikotomi dan menjelaskan kontinumitas agensistruktur. Relasi antara aktor dan struktur terjalin secara dialektik dan saling berkaitan dalam praktik sosial (Haryatmoko, 2016). Upaya penyatuan kedua dimensi tersebut dikenal sebagai strukturalisme genetik, dimana analisa struktur objektif tidak terpisah dari analisa struktur mental individu.

Dalam masyarakat selalu ada kelompok dominan yang menguasai dan kelas yang dikuasai. Dominasi tergantung pada situasi sumber daya (modal) dan strategi penempatan kapital oleh agen (Bourdieu, 2004). Dalam membahas fenomena bullying di sekolah, budaya yang berlaku umumnya merupakan budaya dari kelas dominan. Usaha untuk membedakan diri dari kelas yang lain merupakan bagian dari srategi kekuasaan (Haryatmoko, 2016). 
Penelitian Ariefa (2018) menunjukkan bahwa praktik kekerasan yang dilakukan oleh pelajar dilakukan untuk meraih modal sosial (ikatan sosial dalam pertemanan), modal kultural (nilai keberanian dan agresivitas yang dibangun), dan modal simbolis (menunjukkan identitas). Tujuan tersebut meneguhkan eksistensi sehingga menjadi legitimasi bahwa mereka merupakan pelajar yang disegani dikalangan pelajar. Dalam kasus bullying di sekolah, para pelaku mengkonstruksi identitas untuk menunjukkan perbedaan kuasa dalam relasi sosialnya.

\section{Menggagas Upaya Solutif}

Realitas bullying yang ditandai dengan akar masalah yang tidak tunggal, telah mendapatkan penjelasan teoretik yang lebih mendalam dan komprehensif. Selanjutnya, kajian tersebut diharapkan dapat menghasilkan solusi yang sesuai dengan akar masalahnya. Perspektif determinisme struktur melihat faktor determinan terjadinya bullying sebagai akibat semakin longgar dan lemahnya nilai-nilai sosial dalam masyarakat. Karena perspektif ini melihat faktor struktur yang menyebabkan terjadinya bullying, maka solusi yang umumnya direkomendasikan

berdasarkan pendekatan ini untuk mengatasi bullying adalah melalui penguatan kontrol sosial, pendisiplinan, dan pemberian sanksi kepada pelakunya. Para pelajar yang berpotensi menjadi pelaku bullying perlu diidentifikasi dan dipetakan, apakah bullying dilakukan oleh individu atau bersifat kolektif. Hal tersebut penting karena strategi untuk mentransformasi aktivitas bullying tidak selalu sama antara pelaku individual dan pelaku kolektif. Namun secara umum, mereka perlu diberi wahana untuk mengekspresikan potensi di berbagai bidang peminatan. Dengan demikian, energi negatif dapat dialihkan menjadi energi yang positif dan produktif yang lebih bermakna.

Sedangkan dalam perspektif determinisme agen, karena pendekatan ini memposisikan pelaku bullying sebagai subjek aktif maka muaranya adalah solusi yang lebih bersifat substantif dan kontekstual dengan menggali akar masalah kekerasan spesifik (bullying) dengan mendasarkan pada pandangan agen. Bullying dengan demikian dapat dimaknai sebagai ekspresi eksistensial seseorang untuk menguasai pihak lain. Misalnya untuk meraih reputasi dan status sosial tinggi dalam interaksi dengan sesama pelajar. Sedangkan berdasarkan perspektif kontinumitas 
agen dan struktur, bullying dilakukan sebagai sarana untuk mengembangkan modal-modal seperti modal sosial, modal kultural, dan modal simbolis. Para pelajar pelaku bullying sedang melakukan konstruksi identitas dan mempertahankannya dari waktu ke waktu. Itulah sebabnya, tidak selamanya mudah menghentikan siklus bullying di sekolah.

\section{Simpulan}

Bullying merupakan salah satu jenis kekerasan spesifik yang dapat terjadi dalam konteks persekolahan. Intensitas bullying di sekolah yang menunjukkan peningkatan dengan jenis yang semakin beragam, menuntut jawaban dalam menjelaskan realitas sosial. Akan tetapi terdapat sejumlah jawaban, karena sosiologi merupakan ilmu sosial berparadigma ganda. Dalam tulisan ini, realitas bullying di sekolah dijelaskan dengan menggunakan multiparadigmatik sosiologi, yaitu paradigma determinisme struktur (makro objektif), determinisme agen (mikro subjektif), dan pemaduan (kontinum) di antara keduanya. Artikel ini perlu terbuka untuk dielaborasi dengan menggunakan gagasan lain.

\section{Ucapan Terima Kasih}

Terimakasih disampaikan kepada semua pihak yang terlibat dalam penulisan ini sehingga terlaksana dengan baik dan tim redaksi Jurnal Pendidikan Sosiologi fakultas ilmu Sosial UNY yang telah mempublikasikan hasil karya ini.

\section{Daftar Pustaka}

Alimandan. 1992. Sosiologi IImu Pengentahuan Berparadigma Ganda. Jakarta: Rajawali Press. Affandi, Hakimul ikhwan. 2004. Akar Konflik Sepanjang Zaman: Elaborasi Pemikiran Ibn Khaldun. Yogyakarta: Pustaka Pelajar.

Annot, Kim. 2006. Targeting Bullies: New Details on the Safe School Act. Education Today.

Assegaf, Abd. Rahman. 2004. Pendidikan tanpa Kekerasan: Tipologi Kondisi, Kasus, dan Konsep. Yogyakarta: Tiara Wacana.

Babbie, Earl. 2007. The Practice of Social Research: Eleventh Edition. USA: Thomson Wadsworth.

Bourdieu, Pierre. 2013. Translated by Richard Nice. Outline of a Theory of Practice. UK: Cambridge University Press. 1998. Practical Reason. Standford,Calif: Stanford University Press. 1993. The Field of Cultural Production: Essays on Art and Leisure. New York: Columbia University Press. 1990. Reproduction in Education, Society and Culture. London: Sage. 2011. Choses Dites: Uraian dan Pemikiran. Yogyakarta: Kreasi Wacana. 
Cowie, Helen \& Jennifer, Dawn. 2009. Penanganan Kekerasan di Sekolah: Pendekatan Lingkup Sekolah untuk Mencapai Praktik Terbaik. Jakarta: Indeks.

Day, Christopher \& Gu, Qiang. 2014. Resilient Teachers, Resilient Schools: Building and Sustaining Quality in Testing Times. London: Routledge.

Dake, Joseph A.A. 2003. The Nature and Extent of Bullying at Schoool. The Journal of School Health.

Efianingrum, Ariefa 2018. Reproduksi Kekerasan Pelajar di Kota Yogyakarta. Disertasi. Yogyakarta: UGM.

Fromm, Erich. 2008. Akar Kekerasan: Analisis Sosio-Psikologis atas Watak Manusia. Yogyakarta: Pustaka Pelajar.

Harlin, Rebecca. 2008. Bullying and Viiolence Issues in Childrens's Lives: Examining the Issues and Solutions. Childhood Education.

Haryatmoko. 2016. Membongkar Rezim Kepastian: Pemikiran Kritis Post-Strukturalis. Yogyakarta: Kanisius.

Jatmiko, Sidik. 2010. Genk Remaja: Anak Haram Sejarah ataukah Korban Globalisasi?. Yogyakarta: kanisius.

Jenkins, Richard. 2010. Membaca Pikiran Bourdieu. Yogyakarta: Kreasi Wacana.

Neuman. W. Lawrence. 2000. Social Research Methods: Qualitative and Quantitative Approaches: Fourth Edition. Boston: Allyn and Bacon.

Rigby K. 2002. New Perspectives on Bullying. London: Jessica Kingsley Publisher.

Ritzer, George. 2012. Teori Sosiologi: dari Klasik sampai Perkembangan Terakhir Postmodern. Yogyakarta: Pustaka pelajar.
Saad, Hasballah M. 2003. Perkelahian Pelajar: Potret Siswa SMU di DKI Jakarta. Yogyakarta: Galang offset.

Salmi, Jamil. 2003. Kekerasan dan Kapitalisme: Pendekatan Baru dalam Melihat Hak-hak Azasi

Manusia. Yogyakarta: Pustaka Pelajar. 2005. Violence and Democratic Society: Hooliganisme dan Masyarakat Demokrasi. Yogyakarta: Pilar Media.

Santoso, Thomas. 2002. Teori-teoori Kekerasan. Jakarta: Ghalia Indonesia.

Septiarti, dkk. 2017. Sosiologi dan Antropologi Pendidikan. Yogyakarta: UNY Press.

Spears, Barbara. 2003. Book Review of New Perspectives on Bullying. Journal of Educational Enquiry, Vol. 4, No. 1.

Sumjati. 2001. Manusia dan Dinamika Budaya: dari Kekerasan sampai Baratayuda. Yogyakarta: Bigraf Publishing.

Tjaya, Hidya Th. \& Sudarminta, J. 2005. Menggagas Manusia sebagai Penafsir. Yogyakarta: Kanisius.

https://nasional.tempo.co/read/110958 4/hari-anak-nasional-kpai-catatkasus-bullying-palingbanyak/full\&view=ok 